$\begin{array}{rr}\text { JURNAL } & \text { Volume 10, Nomor 6, Desember 2014 } \\ \text { FIT(1)PATOLOGI } & \text { Halaman } 195-201 \\ \text { I N D O N E S I } & \text { DOI: } 10.14692 / \text { jfi. } 10.6 .195 \\ \text { ISSN: } 0215-7950 & \end{array}$

\title{
Keparahan Penyakit Daun Keriting Kuning dan Pertumbuhan Populasi Kutukebul pada Beberapa Genotipe Cabai
}

\author{
Intensity of Yellow Leaf Curl Disease and Population Growth of \\ Whitefly on Chili Pepper Genotypes
}

\author{
Nissa Fawwaz Adilah, Sri Hendrastuti Hidayat* \\ Institut Pertanian Bogor, Bogor 16680
}

\begin{abstract}
ABSTRAK
Insidensi penyakit daun keriting kuning selalu ditemukan pada pertanaman cabai di Indonesia dan menjadi kendala produksi yang utama. Penyakit yang disebabkan oleh Pepper yellow leaf curl virus (PYLCV) tersebut ditularkan oleh serangga vektor, yaitu kutukebul (Bemisia tabaci). Penelitian dilakukan untuk menentukan respons 6 genotipe tanaman cabai [Meteor, Rimbun, Tornado, F1(12X14), IPBC12, dan 35C2] terhadap infeksi PYLCV dan mempelajari pertumbuhan populasi serangga vektor kutukebul pada masing-masing genotipe tersebut. Penularan PYLCV pada tanaman uji dilakukan menggunakan serangga vektor kutukebul. Kutukebul dipelihara pada 6 genotipe cabai untuk diamati pertumbuhannya. Evaluasi respons 6 genotipe cabai terhadap PYLCV menunjukkan bahwa genotipe IPBC12 tergolong genotipe tahan dengan keparahan berkisar antara $0-9.2 \%$ dan gejala yang ringan. Genotipe Rimbun, Meteor, Tornado, F1(12X14), dan 35C2 tergolong genotipe rentan dengan keparahan penyakit $>20 \%$ dan gejala yang berat. Respons ketahanan genotipe IPBC12 dapat dihubungkan dengan perkembangan kutukebul pada genotipe tersebut. Jumlah telur kutukebul dan persentase keberhasilannya menjadi imago pada IPBC12 relatif lebih rendah dibandingkan dengan 5 genotipe lainnya. Genotipe IPBC12 dapat digunakan sebagai tetua sumber ketahanan pada perakitan varietas tahan PYLCV.
\end{abstract}

Kata kunci: Bemisia tabaci, ketahanan tanaman, insidensi penyakit, serangga vektor

\begin{abstract}
Incidence of yellow leaf curl disease on chili pepper is very common in Indonesia and becomes major production constrain. The causal agent, Pepper yellow leaf curl virus (PYLCV), is only transmitted by insect vector, i.e. whitefly (Bemisia tabaci). Research was conducted to determine response of 6 chili pepper genotypes [Meteor, Rimbun, Tornado, F1(12X14), IPBC12, and 35C2] against infection of PYLCV and population growth of whitefly on each genotypes. Transmission of PYLCV to chili pepper genotypes was done using whitefly. Whitefly was maintained on each chili pepper genotypes to evaluate its population growth. Genotype IPBC12 was resistant to PYLCV having disease severity $0-9.2 \%$ and showed mild symptom. Genotypes Rimbun, Meteor, Tornado, F1(12X14), and 35C2 were susceptible having disease severity $>20 \%$ and showed severe symptom. Resistance of IPBC12 might be correlated with the growth of whitefly on the genotype. The amount of whitefly eggs and its successful rate to become adult was relatively lower in IPBC12 than those in other genotypes. Genotype IPBC12 might be considered as resistance source in developing resistant variety of chili pepper to PYLCV.
\end{abstract}

Key words: Bemisia tabaci, disease incidence, insect vector, plant resistance

*Alamat penulis korespondensi: Departemen Proteksi Tanaman, Fakultas Pertanian, Institut Pertanian Bogor Jalan Kamper, Kampus Darmaga IPB, Bogor 16680

Tel: 0251-8629364, Faks: 0251-8629362, Surel: srihendrastutihidayat@gmail.com 


\section{PENDAHULUAN}

Sejak musim tanam 2003 peningkatan insidensi penyakit daun keriting kuning cabai dilaporkan di beberapa daerah penanaman cabai di Indonesia, terutama di Jawa Tengah. Luas serangan penyakit mencapai $100 \%$ dengan keparahan penyakit yang cukup tinggi. Penyakit daun keriting kuning cabai tersebut disebabkan oleh Pepper yellow leaf curl virus (PYLCV) yang termasuk genus Begomovirus (Tsai et al. 2006). Peningkatan keparahan penyakit pada cabai rawit dan cabai besar didaerah Sleman, Bantul, Kulon Progo, dan Gunung Kidul dilaporkan mencapai 50-100\%. Gejala utama yang ditimbulkan ialah perubahan warna daun menjadi warna kuning yang sangat jelas, penebalan tulang daun, dan penggulungan daun. Infeksi lanjut menyebabkan daun-daun mengecil dan berwarna kuning terang, serta tanaman menjadi kerdil (Sulandari et al. 2006; Trisno et al. 2009).

Penyakit daun keriting kuning cabai ditularkan oleh serangga vektor, yaitu kutukebul (Bemisia tabaci) yang populasinya sangat melimpah saat musim kemarau yang sangat panjang (de Barro et al. 2008). Jumlah kutukebul pada saat penularan mempengaruhi tingginya insidensi penyakit dan masa inkubasi virus. Kepadatan populasi kutukebul pada suatu pertanaman bergantung pada kemampuan peletakan telur imago dan aktivitas makan. Peletakan telur dan aktivitas makan dipengaruhi oleh karakteristik dan morfologi daun seperti bentuk daun, warna daun, trikoma pada daun, dan senyawasenyawa kimia yang dihasilkan dari proses metabolisme sekunder (Lapidot et al. 2001; Ganefianti et al. 2008; Faizah et al. 2012). Pertumbuhan populasi kutukebul yang cepat pada suatu varietas cabai dapat menjadi sumber penyebaran virus yang potensial.

Penelitian bertujuan menentukan respons genotipe cabai terhadap infeksi PYLCV dan kemampuannya dalam mendukung pertumbuhan populasi serangga kutukebul. Genotipe yang memperlihatkan respons ketahanan dapat digunakan sebagai bahan tetua (plasma nutfah) dalam perakitan varietas tahan penyakit.

\section{BAHAN DAN METODE}

\section{Perbanyakan Serangga Vektor dan Inokulum Virus}

Imago kutukebul dan sumber inokulum virus isolat PYLCV berasal dari koleksi Laboratorium Virologi Tumbuhan, Departemen Proteksi Tanaman, Fakultas Pertanian, Institut Pertanian Bogor. Kutukebul diperbanyak pada tanaman kapas dalam kurungan kasa kedap serangga dan PYLCV dipelihara di rumah kaca pada tanaman tomat. Perbanyakan virus pada tanaman tomat dilakukan melalui penularan dengan kutukebul. Kutukebul diberi periode makan akuisisi pada tanaman cabai sumber inokulum awal selama 24 jam, kemudian dipindahkan ke tanaman tomat sehat yang berumur 6 minggu setelah tanam sebanyak 10 ekor per tanaman dan dibiarkan selama 24 jam.Tanaman tomat dipelihara untuk digunakan sebagai sumber inokulum pada uji ketahanan genotipe cabai.

\section{Uji Respons Genotipe Cabai terhadap Infeksi PYLCV}

Genotipe cabai yang diuji terdiri atas 3 galur cabai berasal dari Laboratorium Pemuliaan Tanaman, Departemen Agronomi dan Hortikultura, Institut Pertanian Bogor, yaitu IPBC12, 35C2, dan F1(12X14), dan 3 varietas cabai komersial, yaitu varietas Tornado, Rimbun, dan Meteor. Benih-benih cabai disemai pada medium semai komersial berupa campuran pupuk kandang, kompos, dan sekam. Bibit yang tumbuh dipelihara hingga berdaun 3-4 helai atau berumur 3-5 minggu setelah semai. Bibit kemudian dipindah ke pot kantung plastik berukuran $30 \mathrm{~cm} \times 35 \mathrm{~cm}$ yang telah diisi campuran tanah steril dan pupuk kandang $(2: 1 \mathrm{~b} / \mathrm{b})$ sebanyak $5 \mathrm{~kg}$.

Penularan virus dengan kutukebul dilakukan seperti pada tahap perbanyakan inokulum virus dengan periode makan akuisisi 24 jam, periode makan inokulasi 24 jam, dan jumlah serangga 15 ekor pertanaman. Semua serangga yang digunakan dimatikan setelah periode makan inokulasi.

Percobaan disusun dengan rancangan acak lengkap dengan 6 genotipe cabai [IPBC12, 
35C2, F1(12X14), Tornado, Rimbun, Meteor] sebagai perlakuan. Setiap perlakuan diulang 3 kali dengan 10 tanaman untuk setiap ulangan sehingga jumlah total tanaman pada setiap perlakuan 30 tanaman. Peubah yang diamati meliputi periode inkubasi, gejala, keparahan dan insidensi penyakit. Periode inkubasi ditentukan pada saat gejala pertama muncul. Insidensi penyakit dihitung pada minggu terakhir pengamatan menggunakan rumus sebagai berikut:

$$
\mathrm{IP}=\frac{\mathrm{n}}{\mathrm{N}} \times 100 \%, \text { dengan }
$$

IP, insidensi penyakit; $\mathrm{n}$, jumlah tanaman yang sakit; N, jumlah seluruh tanaman.

Keparahan penyakit dihitung dengan melakukan skoring terhadap gejala penyakit setiap minggunya berdasarkan kriteria tertentu (Tabel 1). Pengelompokkan respons ketahanan genotipe cabai dilakukan menggunakan kriteria ketahanan Ganefianti et al. (2008) (Tabel 2).

\section{Uji Pertumbuhan Populasi Serangga Vektor pada Beberapa Genotipe Cabai}

Uji populasi kutukebul diawali dengan menyiapkan satu tanaman cabai berumur 3 bulan dari masing-masing genotipe uji [IPBC12，35C2， F1(12X14), Tornado, Rimbun, Meteor], kemudian 10 ekor imago kutukebul dipindahkan ke tanaman cabai per kurungan. Sebelumnya pada tanaman dipasang kurungan silinder yang terbuat dari plastik mika yang bagian atasnya ditutup dengan kain kasa. Di bagian tengah plastik mika terdapat lubang yang berfungsi untuk memasukkan imago serangga. Kurungan silinder dipasang pada tangkai daun, masing-masing tanaman dipasang 3 kurungan. Setelah 48 jam, imago tersebut dikeluarkan dari kurungan, kemudian dilakukan pengamatan jumlah telur yang diletakkan oleh serangga. Pengamatan dilanjutkan setiap minggu setelah stadium telur selama 4 minggu untuk menghitung jumlah serangga pada stadium berikutnya.

\section{HASIL}

\section{Respons Genotipe Cabai terhadap Infeksi PYLCV}

Infeksi PYLCVpada 6 genotipe cabai yang diuji menunjukkan gejala berupa penguningan tulang daun dan sebagian lamina daun, serta daun melengkung ke bawah. Periode inkubasi PYLCV pada genotipe Rimbun, Meteor, Tornado, 35C2, dan F1(12X14) berkisar antara 6 dan 15 hari dengan insidensi penyakit berkisar antara $80.0 \%$ dan $96.7 \%$. Insidensi penyakit lebih rendah dijumpai pada genotipe IPBC12 dengan periode inkubasi yang lebih panjang (Tabel 3).

Perkembangan penyakit setiap minggu diamati dengan mengukur keparahan penyakit pada 1-7 minggu setelah inokulasi. Keparahan penyakit meningkat setiap minggunya sampai dengan minggu ke-4 setelah inokulasi pada

Tabel 1 Kriteria gejala infeksi Begomovirus untuk menentukan skor keparahan penyakit

\begin{tabular}{ll}
\hline Skor & Gejala \\
\hline 0 & Tidak bergejala \\
1 & Tulang daun memucat, terlihat bercak kuning pada daun \\
2 & Seluruh tulang daun menguning, sebagian besar lamina daun menguning, daun keriting \\
3 & Sebagian besar lamina daun menguning, daun keriting dan kecil \\
4 & Seluruh atau sebagian besar daun pada tanaman menguning, daun keriting, kecil, dan \\
& tanaman kerdil. \\
\hline
\end{tabular}

Tabel 2 Kriteria ketahanan tanaman terhadap infeksi Begomovirus

\begin{tabular}{lcc}
\hline Respons & Gejala & Keparahan Penyakit (KP) \\
\hline Tahan & Ringan & $1 \%<\mathrm{KP} \leq 10 \%$ \\
Agak rentan & Sedang & $10 \%<\mathrm{KP} \leq 20 \%$ \\
Rentan & Berat & $20 \%<\mathrm{KP} \leq 40 \%$ \\
Sangat rentan & Sangat berat & $\mathrm{KP}>40 \%$ \\
\hline
\end{tabular}


genotipe cabai IPBC12, 35C2,F1(12X14), Rimbun, dan Meteor, kemudian keparahan menurun sampai minggu ke-7. Berbeda dengan genotipe lainnya, keparahan penyakit pada varietas Tornado selalu meningkat setiap minggunya sampai pada pengamatan minggu terakhir. Keparahan penyakit tertinggi terjadi pada genotipe 35C2 (30.8\%), sedangkan keparahan penyakit terendah terjadi pada genotipe IPBC 12 (9.2\%) (Tabel 4). Respons 6 genotipe cabai tersebut dapat dikelompokkan menjadi genotipe rentan [Rimbun, Meteor, Tornado, F1(12X14), dan 35C2] dan genotipe tahan (IPBC12) berdasarkan pada tingkat keparahan penyakit.

\section{Perkembangan Kutukebul pada Beberapa Genotipe Cabai}

Hasil pengamatan populasi kutukebul pada beberapa genotipe tanaman cabai menunjukkan perbedaan jumlah individu serangga pada tiap stadium. Jumlah telur terbanyak diperoleh pada genotipe $35 \mathrm{C} 2$, yaitu 74 telur dan paling sedikit pada genotipe Meteor, yaitu 51 telur (Tabel 5). Keberhasilan telur menjadi nimfa instar awal cukup tinggi, yaitu berkisar antara $74.5 \%$ dan $90.5 \%$, tetapi keberhasilan nimfa instar awal menjadi nimfa instar akhir mengalami penurunan (44.9-71.4\%). Persentase keberhasilan pupamenjadi imago bervariasi antara $64 \%$ dan $80 \%$ (Tabel 6).

Tabel 3 Rata-rata insidensi penyakit dan periode inkubasi Pepper yellow leaf curl virus pada 6 genotipe cabai

\begin{tabular}{lcccc}
\hline Genotipe & Insidensi penyakit & \multicolumn{3}{c}{ Periode inkubasi (hari) } \\
\cline { 3 - 5 }$(\%)$ & $96.7 \pm 5.8 \mathrm{a}$ & $6-15$ & Rata-rata & Modus* \\
\hline 35C2 & $93.3 \pm 11.6 \mathrm{a}$ & $7-15$ & 9.4 & 7 \\
Rimbun & $90.0 \pm 10.0 \mathrm{a}$ & $7-15$ & 9.6 & 7 \\
Meteor & $86.7 \pm 15.3 \mathrm{a}$ & $7-15$ & 9.4 & 7 \\
Tornado & $80.0 \pm 20.0 \mathrm{a}$ & $7-15$ & 9.9 & 7 \\
F1(12x14) & $30.0 \pm 10.0 \mathrm{~b}$ & $9-15$ & 13.0 & 13 \\
IPBC12 &
\end{tabular}

*Modus menunjukkan hari terbanyak munculnya gejala pertama.

Angka yang diikuti huruf yang berbeda menunjukkan hasil yang berbeda nyata berdasarkan uji selang berganda Duncan dengan taraf $5 \%$

Tabel 4 Kisaran keparahan penyakit dan respons 6 genotipe cabai terhadap infeksi Pepper yellow leaf curl virus

\begin{tabular}{lcc}
\hline Genotipe & Keparahan penyakit (\%)* & Respons genotipe \\
\hline 35C2 & $10.0-30.8$ & Rentan \\
Rimbun & $10.0-25.0$ & Rentan \\
Meteor & $10.8-27.5$ & Rentan \\
Tornado & $8.3-29.7$ & Rentan \\
F1(12x14) & $9.2-24.2$ & Rentan \\
IPBC12 & $0.0-9.2$ & Tahan \\
\hline
\end{tabular}

*Kisaran keparahan penyakit diamati dari minggu ke-1 sampai dengan ke-7 setelah inokulasi

Tabel 5 Perkembangan populasi kutukebul Bemisia tabaci pada beberapa genotipe cabai

\begin{tabular}{lccccc}
\hline \multirow{2}{*}{ Genotipe } & \multicolumn{5}{c}{ Jumlah serangga pada tiap stadium } \\
\cline { 2 - 6 } & Telur & Nimfa instar awal & Nimfa instar akhir & Pupa & Imago \\
\hline 35C2 & 74 & 63 & 45 & 34 & 21 \\
Rimbun & 63 & 57 & 36 & 25 & 16 \\
Meteor & 51 & 44 & 24 & 15 & 12 \\
Tornado & 55 & 41 & 19 & 11 & 8 \\
F1(12x14) & 60 & 47 & 27 & 16 & 11 \\
IPBC12 & 58 & 49 & 22 & 15 & 10 \\
\hline
\end{tabular}


Tabel 6 Keberhasilan perkembangan serangga vektor kutukebul pada tiap stadium

\begin{tabular}{lcccc}
\hline Genotipe & \multicolumn{4}{c}{ Nilai keberhasilan perkembangan (\%) } \\
\cline { 2 - 5 } & Tia* & IaIb & IbP & PI \\
\hline 35C2 & 85.1 & 71.4 & 75.6 & 75.0 \\
Rimbun & 90.5 & 63.2 & 69.4 & 64.0 \\
Meteor & 86.3 & 54.5 & 62.5 & 80.0 \\
Tornado & 74.5 & 46.3 & 57.9 & 72.7 \\
F1(12x14) & 78.3 & 57.4 & 59.3 & 68.8 \\
IPBC12 & 84.5 & 44.9 & 68.2 & 66.7 \\
\hline
\end{tabular}

*Tia, fase telur menjadi instar awal; Ialb, fase instar awal menjadi instar akhir; IbP, fase instar akhir menjadi pupa; PI, fase pupa menjadi imago

\section{PEMBAHASAN}

Varietas tahan Begomovirus telah ditemukan pada tanaman tomat dan kacang buncis, tetapi belum banyak informasi mengenai genotipe cabai yang tahan terhadap Begomovirus. Varietas komersial tomat pertama dengan ketahanan terhadap Begomovirus ialah varietas TY20. Tomat galur H24 dengan ketahanan terhadap Tomato yellow leaf curl virus galur Taiwan dan India Selatan telah dilepas sebagai varietas komersial (Hanson et al. 2000). Galur kacang buncis A429 diketahui memiliki ketahanan terhadap Bean golden yellow mosaic virus yang ditunjukkan dengan gejala yang lemah ketika terinfeksi (Singh et al. 2000). Evaluasi yang dilakukan Ganefianti et al. (2008) menggunakan 27 genotipe cabai menunjukkan bahwa IPBC12 tahan terhadap Begomovirus dengan keparahan penyakit < $5 \%$. Pengujian respons 6 genotipe cabai pada penelitian ini mendapatkan hasil yang sama, yaitu keparahan penyakit 9.2\% untuk IPBC12.

Terdapat 2 jenis mekanisme ketahanan yang dimiliki oleh tumbuhan terhadap penyebab penyakit, yaitu ketahanan struktural dan ketahanan biokimia (Lapidot et al. 2001; Faizah et al. 2012). Ketahanan struktural merupakan sifat-sifat struktural tanaman yang berfungsi sebagai penghalang fisik dan penghambat patogen untuk masuk dan menyebar di dalam tumbuhan, sedangkan ketahanan biokimia merupakan reaksireaksi biokimia yang terjadi di dalam sel dan jaringan tanaman yang menghasilkan zat beracun bagi patogen atau menciptakan kondisi yang menghambat pertumbuhan patogen pada tumbuhan tersebut. Mekanisme ketahanan pada genotipe IPBC12 dapat berkaitan dengan struktur morfologi daun dan kemampuan tanaman menghasilkan senyawa inhibitor.Struktur morfologi daun dapat berperan pada kasus infeksi PYLCV melalui serangga vektor. Jumlah, panjang, dan tipe trikoma pada daun dapat mempengaruhi kepadatan populasi kutukebul pada tanaman dan juga berpengaruh terhadap peletakan telur oleh kutukebul pada tanaman. Jumlah telur yang diletakkan pada daun dengan trikoma yang padat dan rapat cenderung lebih sedikit dibandingkan dengan jumlah telur pada daun dengan jumlah trikoma sedikit dan tidak rapat (Suharsono 2006). Ganefianti (2010) melakukan pengamatan terhadap trikoma tanaman cabai genotipe IPBC12 dan 35C2 yang hasilnya menunjukkan bahwa trikoma genotipe IPBC12 lebih banyak dan rapat dibandingkan dengan trikoma pada genotipe 35C2. Hal tersebut dapat menjelaskan jumlah telur pada IPBC12 lebih sedikit dibandingkan dengan jumlah telur pada genotipe $35 \mathrm{C} 2$.

Berbagai faktor berpengaruh terhadap perkembangan serangga sejak stadium telur sampai menjadi imago. Salah satu faktor yang paling berpengaruh ialah aktivitas makan yang dilakukan serangga pada stadium nimfa dan setelah serangga menjadi imago. Aktivitas makan oleh instar awal akan menunjang perkembangannya menjadi instar akhir dan aktivitas makan pada instar akhir untuk berkembang menjadi pupa. Serangga kutukebul menghisap cairan tanaman dengan menusukkan stiletnya. Cairan tanaman yang dihisap merupakan nutrisi bagi kutukebul 
untuk melangsungkan hidupnya. Sama halnya dengan pengaruh peletakan telur, trikoma juga dapat berpengaruh terhadap aktivitas makan serangga kutukebul, khususnya pada stadium nimfa. Pada genotipe IPBC12, trikoma yang rapat dapat menyulitkan kutukebul untuk menusukkan stiletnya, sehingga sebagian besar instar awal kutukebul kekurangan nutrisi untuk perkembangan hidupnya. Hal ini menyebabkan terjadinya penurunan jumlah serangga pada stadium instar akhir. Begitu pula yang terjadi pada perkembangan instar akhir menjadi pupa, yaitu hambatan aktivitas makan mempengaruhi persentase keberhasilan nimfa instar akhir menjadi pupa.

Jumlah serangga vektor merupakan salah satu faktor yang mempengaruhi tingginya insidensi penyakit dan periode inkubasi virus. Jumlah serangga vektor yang tinggi menyebabkan insidensi penyakit semakin tinggi dan periode inkubasi virus semakin singkat, begitu pula sebaliknya (Aidawati et al. 2002). Aktivitas dan perilaku makan serangga vektor sangat menentukan kemampuannya untuk menularkan virus.

Respons 6 genotipe cabai terhadap infeksi PYLCV dapat dikelompokkan menjadi respons tahan (genotipe IPBC12) dan rentan [genotipe Meteor, Rimbun, Tornado, F1(12X14), dan 35C2]. Respon ketahanan genotipe IPBC12 dapat dihubungkan dengan perkembangan kutukebul pada genotipe tersebut. Jumlah telur kutukebul dan persentase keberhasilannya menjadi imago pada IPBC12 relatif lebih rendah dibandingkan dengan pada genotipe lainnya.

\section{DAFTAR PUSTAKA}

Aidawati N, Hidayat SH, Suseno R, Sosromarsono S. 2002. Transmission of an Indonesian isolate of Tobacco leaf curl virus (Geminivirus) by Bemisia tabaci Genn. (Hemiptera: Aleyrodidae). Plant Pathol J. 18(5):231-236. DOI: http:// dx.doi.org/10.5423/PPJ.2002.18.5.231 .

De Barro PJ, Hidayat SH, Frohlich D, Subandiyah S, Ueda S. 2008. A virus and its vector, Pepper yellow leaf curl virus and Bemisia tabaci, two new invaders of Indonesia. Biol Invasions. 10:411-433. DOI: http://dx.doi.org/10.1007/s10530007-9141-x.

Faizah R, Sujiprihati S, Syukur M, Hidayat SH. 2012. Ketahanan biokimia tanaman cabai terhadap Begomovirus penyebab penyakit daun keriting kuning. J Fitopatol Indones. 8(5):138-144. DOI: http://dx.doi. org/10.14692/jfi.8.5.138.

Ganefianti DW. 2010. Genetik ketahanan cabai terhadap Begomovirus penyebab penyakit daun keriting kuning dan arah pemuliaannya [disertasi]. Bogor (ID): Institut Pertanian Bogor.

Ganefianti DW, Sujiprihati S, Hidayat SH, Syukur M. 2008. Metode penularan dan uji ketahanan genotipe cabai terhadap Begomovirus. Akta Agrosia. 11(2):162169.

Hanson PM, Bernacchi D, Green SK, Tanksley SD, Muniyappa V, Padmaja AS, Chen H-M, Kuo G, Fang D, Chen JT. 2000. Mapping a wild tomato introgression associated with Tomato yellow leaf curl virus resistance in a cultivated tomato line. J Amer Soc Hor Sci. 125(1):15-20.

Lapidot MM, Friedmen M, Pilowsky R BJ, CohenS.2001.Effect of hostplantresistance to Tomato yellow curl virus (TYLCV) on virus acquisition and transmission by its whitefly vector. Phytopathology. 91:12091213. DOI: http://dx.doi.org/10.1094/ PHYTO.2001.91.12.1209.

Singh SP, Morales FJ, Miklas PN, Teran H. 2000. Selection for Bean golden mosaic resistance in intra- and inter-racial bean populations. Crop Sci. 40:15651572. DOI: http://dx.doi.org/10.2135/ cropsci2000.4061565x.

Suharsono. 2006. Antixenosis morfologis salah satu faktor ketahanan kedelai terhadap hama pemakan polong. Bul Palawija. 11:29-34.

Sulandari S, Suseno R, Hidayat SH, Harjosudarmo J, Sosromarsono S. 2006. Deteksi dan kajian kisaran inang virus penyebab penyakit daun keriting kuning cabai. Hayati. 1(13):1-6. 
Trisno J, Hidayat SH, Jamsari, Manti I, Habazar T. 2009. Detection and sequence diversity of Begomovirus associated yellow leaf curl disease of pepper (Capsicum annum L.) in West Sumatra, Indonesia. J Microbiol Indones. 2:61-66.

Tsai WS, Shih SL, Green SK, Rauf A, Hidayat SH, Jan FJ. 2006. Molecular characterization of Pepper yellow leaf curl
Indonesia virus in leaf curl and yellowing diseased tomato and pepper in Indonesia. Plant Dis. 90(2):247. DOI: http://dx.doi. org/10.1094/PD-90-0247B. 